\title{
The Media of Washatiyah Dakwah in Quranic Exegesis Study
}

\author{
Andri Nirwana ${ }^{1}$, Hayati ${ }^{2}$, Muhammad Ridhwan ${ }^{3}$ \\ ${ }^{1}$ Qur'an and Interpretation Study Program, Faculty of Islamic Religion, Universitas Muhammadiyah \\ Surakarta, Indonesia \\ ${ }^{2,3}$ Universitas Serambi Mekkah, Banda Aceh, Indonesia \\ andri.nirwana@ums.ac.id,hayati@serambimekkah.ac.id,muhammad.ridhwan@serambimekkah.ac.id
}

\begin{abstract}
the fact explains that the Islamic media in the late 70s-90s tended to be provocative, brave, straightforward and resolute in raising issues and themes that were sensitive and offensive to ethnicity, religion, race and interfaith (SARA) and dared to carry ideology, exclusivist and fanaticism that strong against Islam, even though at that time media freedom was very limited. After the $90 \mathrm{~s}$ the media became free in handling and publishing. Unfortunately this condition is not exploited by Wasatiyah Islamic Media. This media tends to sink due to competition in the media business. The decline of wasatiyah Islamic Media was due to imperfect management. The obstacles in presenting news that are fast, easy and inexpensive require good management. Another challenge is how to provide intelligent reading that follows the development of increasingly intelligent humans and provides a binding and enlightening impression. As a result of the deterioration of management, other Islamic media have the opportunity to spread the news of hate speech and hoaxes. To this problem we use the Thematic Interpretation Method of the Qur'an to provide concepts and descriptions of the Qur'an based Wasatiyah media. The results of this study stated that Wasatiyah Islamic Media must understand the Counter-Radical Narrative Narratives spread by other media. So in providing comments and information must be based on Islam Rahmatan lil alamin. Wasatiyah Islamic Media Must understand the weaknesses of the radical media editors. Wasatiyah Islamic media must play a role and provide moderation for religious and Islamic thought in line with the Unitary State of the Republic of Indonesia. Editor of the Wasatiyah Islamic Media must depict editors who are more humane, polite, not hard, without coercion, full of tenderness and voluntarily. The results of this study have an impact on the unity and sovereignty of the Republic of Indonesia.
\end{abstract}

Keywords

Tafsir, dakwahmedia

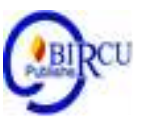

\section{Introduction}

Religion has a function to foster brotherhood especially among internal religious communities. But like the two sides of the religious coin, it has a dual role to play between integrative functions and disintegrative functions in social reality, depending on the context of internal or external relations of religious communities. (Muda et al, 2020)

Media is a very important factor in shaping image, image and stigma. Through the media information can be obtained reality that is taking place elsewhere, even though the reality displayed by the media, is not actual reality. But this reality has been polished in such a way by the media crew. The concept of framing played by the media crew is also used by the Radical media, so that when read by non-Muslims it gives an uncomfortable 
descrption. The concept of framing can dictate the brain to understand reality without being aware of the truth, the media portray an event by highlighting certain aspects and at the same time placing information in a specific context, so that the issue gets special attention compared to others.

\section{Review of Literature}

\subsection{Definition of Media}

Media is a tool to share or spread information or news to the people. Media is divided into two that is print media and electronic media. Print media is like news paper, magazine, etc. And electronic media is like television, radio, hand phone, internet, et cetera (Hamid, 2016). According to the epistemology, dakwah from word "da'a, yad'u, da'watan". That means persuade people to do good things, good behavior, good attitudes, good perceptions. What Allah asked and leave what Allah forbidden.

According to Muhibuddin (2019) the word d'wah has several meanings including: first, al-nida means to invite; da'ā fulānun ilā fulānah, meaning someone invites the polan. Second; called on; ud'u ilā al-syai'i, which means to call and push for something. Third; al- , meaning to affirm it or defend it, whether something is right or vanity, positive or negative. In carrying out the da'wah movement, of course, requires the media to support the activities of the da'wah movement (Zulfikar, 2020).

QS. Ibrahim (14) : 4

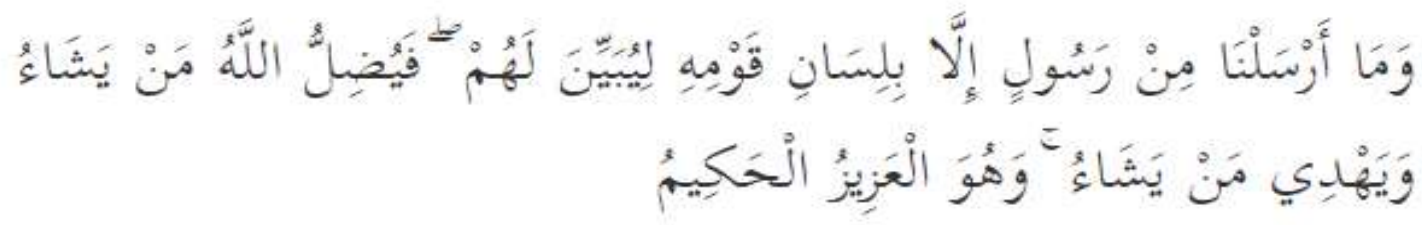

The translation of verse:

We do not sent a Prophet, but with the language of his people, so that he can explain clearly to them. So God is misleading whom he wills, and give guidance to whom He will. $\mathrm{He}$ is the Lord Almighty, Most Wise again. (14:4)

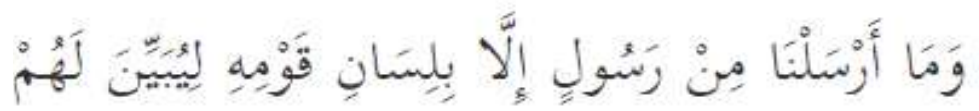

"Billisani qaumihi" means that "balagha qaumihi", is using the language of his people. The purpose of that verse is "we do not sent a Messenger to a people before you, that he can easily know what the comman, and what Allah prohibited. If the Qur'an brought by the Prophet with their language, why they do not want to understand and ask the meaning, such as a variety of lessons and laws, so that they gain happiness in the world and the Hereafter.

Based on the Sunnah and kindness, God had not sent an prophet to a people, but in a language that is understood by the people, therefore every Messengers serves only to convey the message of Allah all of moslem only.(Yusuf, Zain, \& Fuadi, 2017) Different from the prophet Muhammad, his message is not only delivered on a people or a nation, but to all the people, as the last prophet. The Word Allah in the Al-Anbiya (21): 107. 


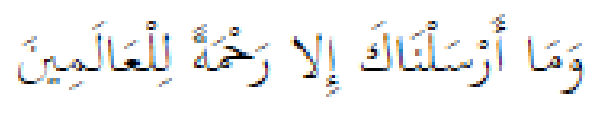

Meaning: There is not we sent you but as a mercy for the universe.

Although the Al-Quran and Hadith in Arabic, but it was not intended for Arabs only, but to all human beings. Interpretation Al-Quran which is considered capable of being a solution of the above conditions experienced extraordinary development. The interpreter, armed with his knowledge, develops the method of interpreting Al-Quran on an ongoing basis to supplement deficiencies or anticipate misappropriation or to analyze more deeply the existing interpretations (Hasbullah, 2019). The Prophet Muhammad convey the news all of muslims in Arabic, and his people, who will explain his teachings to other people with their own language so that teaching is easy to understand. If the teachings is revealed through a variety of languages, it will be difficult to understand, and there will be clashes or problem between them.(Zulkifli Hj.Mohd Yusoff, 2003)

God will mislead whom he wanted and give guidance to whom He wills. Muhammad Asad says that all the verses of the Quran which says that "Allah mislead whom he wills" should be understood with reference to the background QS.Al-Baqarah (2): 26-27 "It is not God who causes him to get lost but he had broken, deny and do not want to obey to Allah ", because it's someone who is said to be mislead because the consequences of the attitude or actions, not of destiny.(Muhammad Chirzin, 2013)

Al-Zamakhsyari emphasize the aspect of (free choice) man by saying that "God does not cause people to mislead except God who know would not believe, and Allah dont give a person to the truth unless someone knew would believe. Thus the expression "Allah will mislead" is understood that God leave somebody (Takhliyah), while the expression "Allah gave guidance " understood the love and grace of God.(Zulkifli Hj.Mohd Yusoff, 2003)

Allah will make misleading anyone except those who get it, and will give favors to people who get it. In interpreting the phrase which is identical to the QS. Al-Nahl (16): 93, Zamakhasyari said "God would mislead someone he knows will consciously choose denial or the wrong path than the truth. and he gave instructions that those who believe in Allah. This means that God gave us the freedom to choose, good or bad, depending on our own.(Syahnan, 2017)

Based on the verse, people were divided into two groups, namely: the ones who were given instructions by God Almighty, her spacious and illuminated to accept Islam and then follow the straight path. The second category is those whose hearts have been sealed by the heretical because it always sin and immorality. Each group's destiny and the will of Allah, no one can resist its provisions, and others can not sue the law.

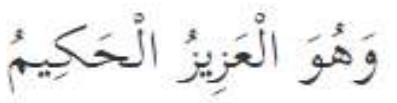

God is mighty, and no one can distract and most wise. Allah do and decide everything. When we live, we die, only God knows about it, even a leaf falling from a tree, has been established by God. God is extraordinary. As word of Allah in the Qur'an. Al-Fath (48): 23.

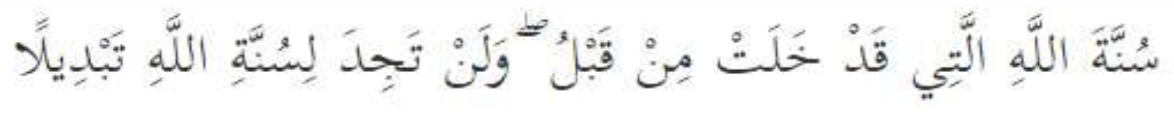


As the laws which has prevailed since long ago, you will not be able to determine changes for sunatullah it. Sunatullah is the laws of Allah that has been established or commonly also called "denural ofgan" laws of nature (natural of law).

As a da'i, verse provides the basis that the mission is to understand the object of religious. Besides it is necessary to understand the condition and what material will be delivered. Also the ability to buy some religious books, magazines, video download religions, such as "mama Dedeh, ustad Maulana" and others, that there is a message about religious. You can find information from it. Because now is the time globalization era. This is in line with the hadith of the Prophet: From Maimun bin Syabib, the prophet said: Treat or confront (deal) human being according degree or level of them. In another hadith the Prophet said:We commanded in order to speak to the people according to the levels of intelligence of them (HR. Muslim).(Khan, 1985)

So, to find out how the condition and reasonable or mainset owned by mad'u, a da'i must do approach the first, to find factual data about one person or organization or society. Then he can make the methods and media of religious. Because observation or research something is very important, thats is the first step to know about our mad'u.(RI, 2010)

\subsection{Tafseer}

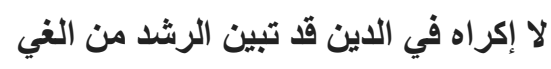

The letter "لا" in this verse is "لأنافية" (negate), but in the mean is nahy (ban). So maknanyan is: jangalah force someone to convert to Islam. In addition there is also the opinion that "لا النافية does not mean nahy, but rather serves as a khabar. Therefore, it means: that Allah does not establish religion on the basis of coercion but fostered on the basis of effort and freedom. Precisely should never force someone to enter the religion of Islam.

Ibn Kathir explains the meaning of "لا إكر اه في الدين" with: Do not force a person to enter the religion of Islam as the religion of Islam was clear and evident once the arguments and explanations, do not need someone forced entry. Even who were given instructions by God to convert to Islam and expanded his heart to accept Islam and was given nur (light) his mind's eye he went into Islam based on the evidence and the instructions were real. He who closed his heart by Allah so did hearing and eyesight, then coercion and violence will not be beneficial for them to enter into Islam.(Ad-Dimasyqi, 2000)

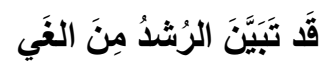

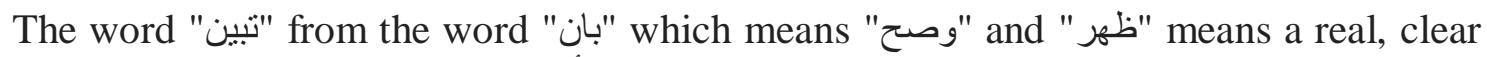

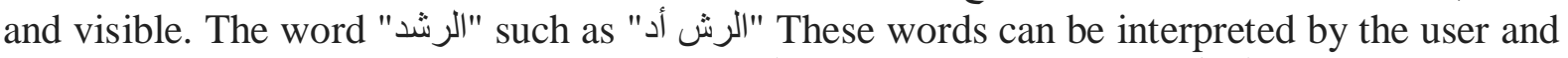
used unutuk all goodness. Keblikannya is "الجني" (الجك" ignorance). AlRushd can also mean "straight path" while al-ghayyu meaning "crooked path". It's just that the word al-jahlu regard to fi'liyah (deeds), while al-ghayyu associated with I'tiqadiyah (confidence). So to eliminate ignorance is with knowledge penegtahuan and to eliminate alghayyu are instructions or guidance.(Ad-Dimasyqi, 2000)

The intent of this paragraph is already clear that the right path (Islam) and the wrong way (disbelief), so people do not need to be forced Memluk agam Islam. Moreover, Islam is a matter of faith, and faith is of the heart, whereas a person's heart can not be forced to believe or like something. Paragraph tune with the verse, which is the word of Allah in Surah Al$\operatorname{Kahf}(18): 29$ :

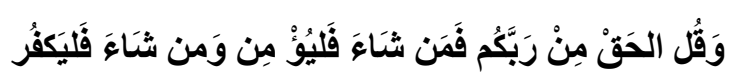

"Say: The truth comes from your Lord, so whosoever wants (believer) hendalaklah he had faith. And whoever will infidels, let him disbelieve". 
The word "الطغاغوت " berasla of the word "التغيان meaning beyond the limit in some way. thaghut word may mean simplex and plural and may mean muannas and mudzakar.

Said thaghut also mentioned in QS. Al-Nisa (4): 60

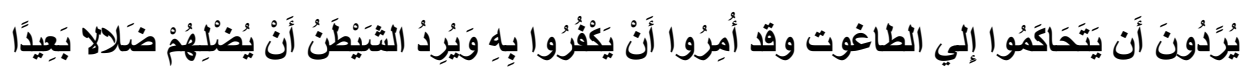

"They want berhakim to Evil, even though they had been instructed to deny taghout it. And what the devil intends to mislead them by the deception that as far as possible".

That the intention thaghut in this paragraph is the one who is always hostile to the Prophet and the Muslims and some say Abu Barzah, a weaver at the time of the Prophet. Also included thaghut namely: those who cheat procedural law has been set by lust and idols. As for the word "مسك" "استمسك" comes from the word "مhن means holding or hold.

According to al-Maraghy anyone who denies things go astray, such as worship fellow humans, syaiyan, idols or follow the will of the leader is wrong and immoral, but rather faith in Allah, worship Him alone, expecting forgiveness and good pleasure His, believing him to the apostles who were requested to convey his orders and prohibitions, good tidings and warnings for the benefit of humans.(Hadi, 2014)

In addition, he holds fast to aqidah and practice it, then he is like one who has bepegang the safety rope shelter under the banner of truth is very sturdy. This can only be achieved if a person holds a strong rope that is not worried about breaking up with a very large load and strong.

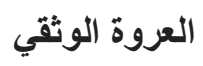

The word "الوثق" meaning rope terbuhul hard and strong. According mujahid is meant by "al-urwat al-wutsqa" is faith, while al-Suddy say that the question is Islam. And Dahhak said that the intention is la ilaha illa Allah. According to al-Qurthubi in third position this opinion is the same as everything returns back to one sense or the intent.

From the description it can be concluded that, "العروة الوثقي is the Islamic faith and that is a very strong grip. So whoever believeth in Allah SWT in accordance with the guidance of Islam and deny the existence of something that is worshiped aside from Allah, such as idols, actually she has had a solid grip, it will not break or fall apart again. Conversely those who do not believe in Allah or worship something other than Allah verily grip is very fragile and easily disconnected.(Ad-Dimasyqi, 2000)

Word of Allah in Surah Ankabut (29): 41:

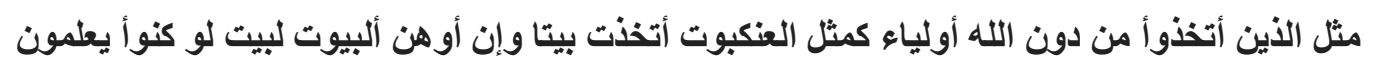

The parable of those who take protectors other than Allah is like the spider who makes house. And indeed the weakest house is the house spider if they only knew.

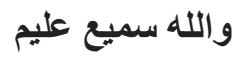

The word "سميع" when attributed to Allah means something that stands alone on the nature of Allah on him what is heard or sounded without the sense of hearing.

According to al-Maraghi, this verse implies that Allah Maha heard talk of people who deny thaghut and faith in Allah. Allah knoweth what is in his heart, whether true or false confession. People who believe that everything goes according to the power of Allah, there is 
no power that influence a person, then he is the one who truly believe and are entitled to a reward perfect. Instead people are still affected his confidence in the power of idols and his magical powers to help someone closer to Allah SWT, then he is entitled to receive an ordeal. The torment that will be received is equal to sikasaan people who claim to believe in Allah and the last day orally but their hearts do not believe.(Hadi, 2014)

Muslims make this verse as a principle of religion and politics is very high, so they do not justify the imposition of religion to anyone, just as a person does not justify forcing people out of the Islamic religion. In addition to protecting the people of weak faith, so that it can grow up to be strong and prevent defamation infidels against Islam, as it had been in its natural Muslims in Mecca overtly religious freedom blocked, so there came the Word of Allah QS. Al-Baqarah (2): 193

$$
\text { وقتلو هم حتي لا تكون ففتنة ويكثثون الذين فإن أنتحوأ فلا عدون إلا علي الظلمين }
$$

Fight them, so there is no more fitnah and so compliance is solely for Allah. If they are stopped from hostile to you then no more hostility except against wrong-doers.

\section{Discussion}

\subsection{Non-Discriminatory Towards the Object of Dakwah (Proselytizing)}

Allah Said in Q.S Al-Anam (6) : 52

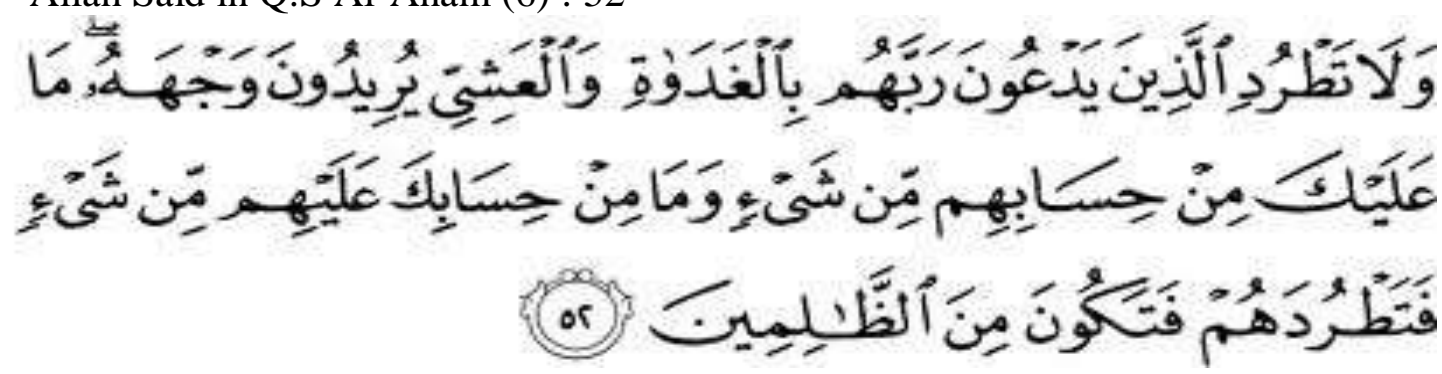

"An do not you expel those who call god in the morning and in the evening, while they willed His pleasure. You do not bear the slightest responsibility towards their actions and they do not bear the slightest responsibility towards your deeds, that caused you (entitled) expel them, so that you are one of the wrongdoers."

\section{a. Asbabun Nuzul}

This verse was revealed in connection with six friends who are on the side of the Holy Prophet saw they have such Sa'ad ibn abi Waqqas and Abdullah ibn Masud. When the unbelievers Quraysh said to the Prophet saw peace be upon him: "cast them because we felt ashamed of being followers as they despised it." words of unbelievers is very barb Prophet of Allah swt. This connection with Allah revealed this verse as a prohibition against the Muslims undertake an assessment of the dignity of a person and distinguish his rank and position in the association (HR. Ibn Hibbaan and Judge of Sa'id ibn abi Waqqas). (Alifuddin, 2012)

In another narration at the time of the magistrates of the pagan Quraysh passed before the Prophet peace be upon him sitting with Khabab bin Arat, Suhaib, Bilal bin rabbah and Ammar bin Ysir a slave who had been freed, they said: O Muhammad saw, would you be willing to sit level with them. Whether they had been given favors by Allah more than we have.If in case you do not mind of course we will drive them into followers of your teaching. "In connection with that Allah revealed this verse as firmness and prohibitions against Muslims held a vote against the dignity of others (HR. Ahmad, Thabrani and Ibn Hatim Ibn Masud).” (Shihab, 2009) 
Other versions mention that at a time Utbah bin Rabi'a, Mut'im bin Harith bin Nawfal Adiy and magnifying pagan Quraysh from among the sons of Abd Manaf came to the Abi Talib, the Prophet's saw uncle and father friend of Ali and said: " O abi Talib, if in case your brother's son (Muhammad saw) are willing to drive out the slave who was at his side, of course we will be happy and it will be his obedient and loyal to him." Abi Talib convey this offer to the Prophet. Heard this offer directly Umar said, "if only thou, O Prophet of Allah, fulfill their requests, we will see what will happen and what will they ask for more." in connection with this event Allah swt revealed this verse as a command to the firmness of the Prophet to convey the revelation about the ban expel that have been worshiping Allah swt dignified even if they are low. Besides this verse also states banning conduct an assessment of the person's dignity, for Allah is knowing the circumstances Those who always give thanks to Him. (HR. Ibn Jarir from Ikrimah).(Ad-Dimasyqi, 2000)

\section{b. Exegetic}

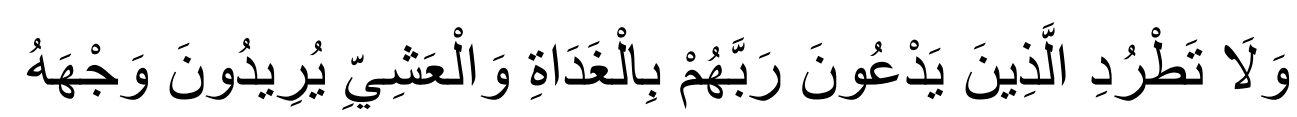

This verse fragment meaningful $O$ Messenger of Allah swt ye shall drive out the believers who belief in one god (Allah), who pray to the god of time when the morning and evening. Prayer here could mean prayer, prayer is a form of prayer. Prayer in the early days of Islam held in the morning and afternoon. Yuriduna wajhah, interpreted by them to pray to the god of good time when the morning and evening for want of approval. Such an interpretation can be seen in QS. Al-Insan (76): 9.

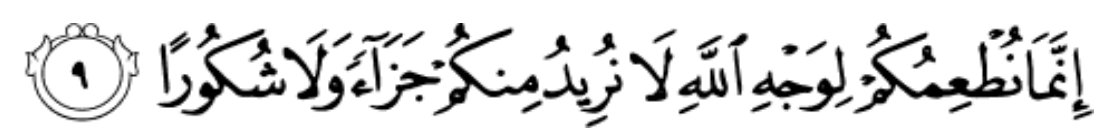

"Indeed, we give food to you is to expect the good pleasure of Allah, we do not want a reply from you, nor (speech) thank you."

There are similarities between the public response to the preaching of the Prophet with the response given earlier to the followers of the apostles were sent to them. The first equation is that those who first followed his teachings are among the weak and poor. The second equation is in terms of the enemy they faced, they were likely to insult those who first followed the teachings of the Holy Prophet and they are not willing to be treated the same as these people.(RI, 2010)

The argument can be seen from the attitude of the followers of the former apostles of Allah, for example, to record the words of the leader of the infidels against Noah as set out in QS. Hud (11): 27.

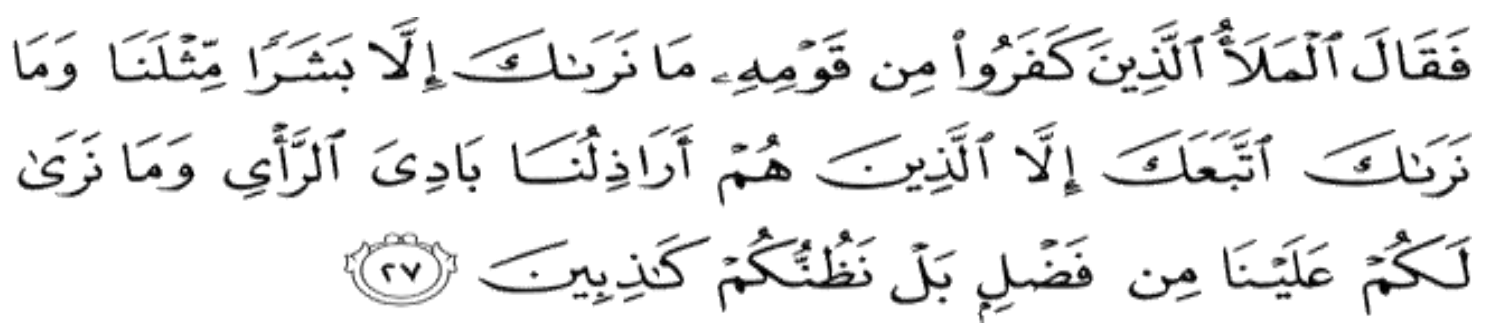

"then said leaders who disbelieved among his people: "we do not see you, but (as) a man (usually) like us, and we did not see the people who follow you, but those who are lowly among you who quickly trust alone, and we do not see in you any merit above us, in fact we believe that you are the ones who lie." 
Though Noah, take a hint desire of the leaders of the infidels to ask him to drive away the poor who are already believers, he still will not do it, because his job is just a warning. Noah's stance among others, can be seen in the QS. Al-Syu'ara '(26): 114-115.

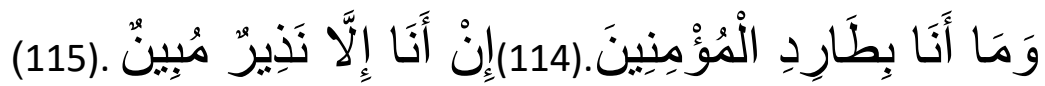

"And I'm never going to drive out those who believe. I (was) nothing else but a warner to explain. "

Similar statements mentioned in QS. Hud (11): 29

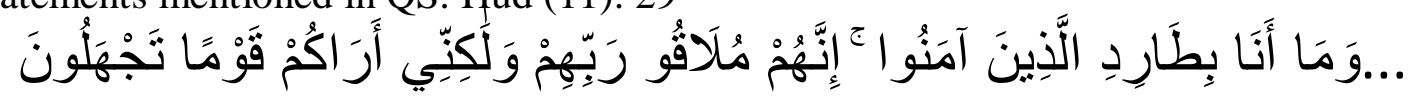

....."And I'm never going to drive out those who believe: verily they will meet with his god, but I look at a people who do not know."

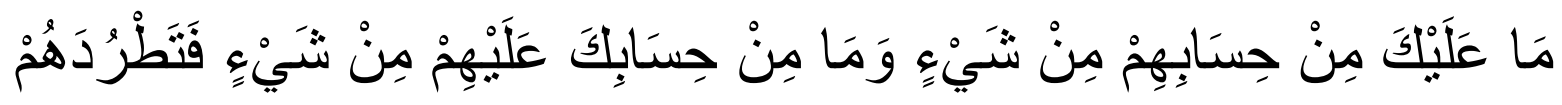

According to Al-Maraghi, this verse is understood that the apostles did not have the authority to do the reckoning of the actions of people who call on their Lord morning and evening. The consequences are apostles did not have any reason to expel them by claiming their bad deeds. Otherwise they would not have any reason to act menghisab apostles. Right judgment only to Allah, not the Apostles.(Hadi, 2014)

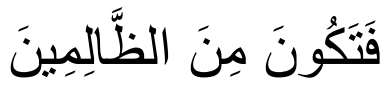

This verse indicates that the expulsion could bring the perpetrators of injustice. Based on the expulsion of the bad things, after the judgment and retaliation for a charitable act which belongs fully to God Almighty. Allah Almighty says in the Qur'an. Al-Shu'ara '(26): 113.

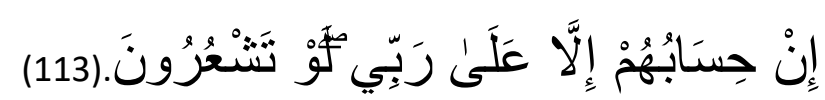

Calculation (deeds) they are nothing but my Lord, if you realize.

To convey the same statement that paragraph, namely QS. 'Abasa (80): 1-2.

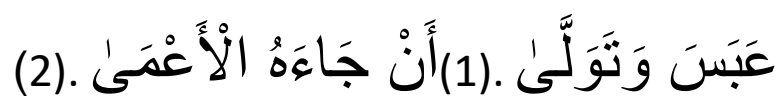

He (Muhammad) frowned and turned away, because the blind man came head.

There are two versions about the cause Nuzul this verse: version mentions, according to a history, at one time the Prophet receive and talk with the leaders of Quraysh like Utbah bin Rabi'a, Abu Jahl, Abbas ibn Abd al-Muttalib, Ubay bin Khalaf and Umayya bin Khalaf, which he expected to convert to Islam. In the meantime came Abdullah bin Umm Maktum, a blind friend who hoped that the Prophet recited the verses of the Qur'an which was revealed to him by Allah. But the Prophet frowned and turned away from Ibn Umm Maktum who was blind, then Allah bring down this sura as strikes over the attitude of the Messenger of Allah to him.

Interpreter An Enlightening Commentary in The Light of the Holy Qur'an Another version suggests because nuzul this paragraph, that a man of the Umayyad was sitting next to 
the Prophet Muhammad, at that time Abdullah Ibn Umm Maktum came when the people saw Abdullah he turned it over. Informed that Imam Sadiq agree with this when he was asked about this paragraph because nuzul. The late Sayyed Murtaza, scholar of Islam accept this because nuzul.(Zuailan, 2016)

It seems there is no indicator in this verse which shows clearly that he intended to Muhammad, the only signal can be found in paragraph 8 to 10 when they say: "and as for the people who come to you in haste (to get teaching), being he fear (Allah), then you ignore it. " this indication may be right about the Prophet Muhammad than anyone else. But according to what has been said Sayyed Murtaza, there are some signals in the paragraph that indicates that the person in question is not the prophet Muhammad. Several reasons can be stated as follows:

Turned away is not the character and behavior of the prophets, especially the Prophet of Islam, he spoke kindly to face sweet indeed even to his enemies and certainly more polite again to the believer who is always searching for the truth. More than that devote attention to the rich and ignore the indigent person thinks can not be in at all with what has been said about him in the QS. Al-Qalam (68): 4. "And ye truly virtuous character is great." (Note that the surah Al-Qalam has been revealed before surah 'Abasa).

But suppose because nuzul first version is correct, as this action is nothing more left something to get better and not contained therein are contrary to the status of infallibility. The first reason, the purpose of the prophet are apasti to influence the leaders of the Quraysh in order to spread Islam and stop sabotage. The second, not so a problem to look away from the blind man because he can not melihat.lebih of the Abdullah bin Umm Maktum not obey the rules of ethics, because he really did not interrupt the Prophet and when he was busy talking to the people who gathered there.

On the contrary, because the God emphasis is on love and affection to the poor and destitute, among the believers, not the slightest lack of attention proven Apostle to the faithful slave, therefore he appreciates it. On the other hand, if we menggangap Prophet, as a truth the great Prophet, from these verses we see that it was a miracle, because the great leader of Islam mention some important responsibilities in the scriptures about himself that he found leaving for get something better as an option: the small number of less concern to a blind believer who seek the truth, which God swt makes warning. This is a proof of the fact that this book of Allah and he is a great prophet, because if the book is not of God swt, he certainly does not contain such material.(Zulkifli Hj.Mohd Yusoff, 2003)

The only thing more amazing is that according to the history, no matter where the prophet saw Abdullah ibn Maktum, he recalls the incident and give him the respect it deserves. Another aspect that contained the verse is that Islamic culture in relation to behavior aimed at the arrogant people of oppressed people: like how she considered believers who are blind and poor in comparison to the leaders of the rich Arab polytheists longer in power. This clearly shows that Islam is a support for the oppressed and against the arrogant.

Conclusion, we reiterate that, notwithstanding history because the first version of the famous verse nuzul among commentators, be emphasized that there were no definite cues in this verse to refute the view that the Holy Prophet saw became clear goal of the commemoration. The implications of the interpretation of the second paragraph, namely that a da'i should treat equally each object of propaganda. Preaching ministry is not only given to specific groups that may be invisible to the eye more profitable, better economic, political or social status.

Which means the Da'wah invited and called on people to practice the teachings of Islam, certainly contains messages that should be conveyed Islam. Propaganda material sourced from al-Quran and al-Hadith, penjabarannya discussion was divided into three 
groups, namely: aqidah, syariah, and morality. All the elements that is the subject matter of propaganda. As the subject matter of the Quran and al-Sunnah, a preacher should be able to pass it on to others according to the languages he speaks. It contains instructions, guidelines, laws, history, problems, faith, worship, relationships and morality and science. In general, the basic content of the Qur'an covers various aspects that lead humanity to be able to understand, believe and also practice it in daily life, among others, namely: faith, worship, mua'malah, morality, history, science basics science and technology as well as a description of the instigation, promises, and threats.(Syarafuddin, 2017)

\section{Conclusion}

Broadly speaking, the material is all the teachings of Islam propaganda kaffah that can not be separated or broken down, as described in the Qur'an and Hadith as well as more widely developed in accordance pure Islamic culture and sourced from both. But even so, it must be realized that in the delivery of propaganda material also requires other priorities, such as social circumstances are right. The object of propaganda the prophet saw at the beginning of prophethood is the arab society of ignorance or a society that is gentleness in the time of ignorance. Stupidity arab society at that time located in the field of religion, morality, and law. In the field of religion, the community arab time it had strayed away from the teachings of the religion of monotheism that has been taught by the apostles earlier. They are predominantly pagan religions. Idols they worship was placed around the temple are huge numbers. In terms of morality, ignorance arab people have bad habits, namely gambling, drinking, stealing, committing adultery, etcetera.(Piloting et al., 2012)

The purpose of propaganda Rasulullah arab saw is that people leave kejahiliyahannya in the field of religion, morals and laws so that a people who believe in the kerosulan Prophet Muhammad and the teachings of Islam conveys, then practice it in daily life. If the Arab societies have practiced all the teachings of Islam with sincere intentions because Allah swt and according to the instructions The directions Rasulullah would obtain salvation of the world and the hereafter. The Prophet Muhammad is a personal being virtuous and noble. He deserves to serve as a role model and idol of us as Muslims. Moral glory Prophet Muhammad recognized by the community of Mecca with a given Al-amin as a trusted person. Allah swt praised him as a man with great personal. Deserves this greatness deserve it bears for him as the last prophet who is able to inherit all the attributes and virtues possessed earlier prophets. Muhammad was always concerned about other people's suffering, groaning people always ditanggapinya and always helping people in trouble. He always fulfill the promise, happy to forgive his enemies who had hurt him, patiently when wronged, very generous, courageous, he is very tawadhu far from being arrogant. In terms of features, rosulullah saw never want privileged and always strives to eliminate discrimination and excessive respect to him.(Shah, 2013)

Prophet Muhammad is the best example in all aspects of life. No man is so perfectly imitated for whom there are precious nature. In addition, rosulullah saw also experienced various circumstances in his life. He never experienced life as hard so it can be an example for people who are experiencing difficulties. He was a rich man so that it can be an example of how to use the wealth. He was also a leader in various fields so that we can follow the example of his leadership. In leading his mission armed with patience, confidence, perseverance and tenacity and ignoring the idolaters who continue rebuked and insulted.(Marthoenis, Nirwana, \& Fathiariani, 2019) 


\section{References}

A.M iSNATULLOH. (2010). Konsepsi Ibnu Jarir Al-Tabari Tentang Al-Qur'an, Tafsir Dan Ta'wil. Fenomena.

Ad-Dimasyqi, A.-I. I. K. (2000). Tafsir Ibnu Kathir. Tafsir Ibnu Kathir.

Alifuddin, M. (2012). Asbabun Nuzul dan Urgensinya dalam Memahami Makna Qur'an. Shautut Tarbiyah.

AN, A. N. (2013). Konsep Islamic State Amien Rais dan Nurcholish Madjid. SUBSTANTIA. https://doi.org/10.1017/CBO9781107415324.004

Arifin, Z. (2013). Studi Kitab Hadis. SRUDI. https://doi.org/10.1364/OL.36.000127

Hadi, M. K. (2014). Karakteristik Tafsir Al-Marāghī Dan Penafsirannya Tentang Akal. Hunafa: Jurnal Studia Islamika. https://doi.org/10.24239/jsi.v11i1.345.153-172

Hambali, S. (2013). Astronomi Islam Dan Teori Heliocentris Nicolaus Copernicus. AlAhkam. https://doi.org/10.21580/ahkam.2013.23.2.24

Hamid, S. A. (2016). Pengaruh Media Massa Terhadap Perubahan Sosial Masyarakat. Journal of Social Sciences and Humanities.

Hasbullah, et al. (2019). Messages Communication in the Al-Qur'an (Study of Messages in the Al-Qur'an for Believers). Budapest International Research and Critics Institute (BIRCI-Journal): Humanities and Social Sciences, 125-131.

Khan, M. M. (1985). Sahih Bukhari. Sahih Bukhari.

Marthoenis, M., Nirwana, A., \& Fathiariani, L. (2019). Prevalence and determinants of posttraumatic stress in adolescents following an earthquake. Indian Journal of Psychiatry. https://doi.org/10.4103/psychiatry.IndianJPsychiatry 3519

Muda, I and Suharyanto, A. (2020). Analysis of life's inter-religious harmony based on the philosophy of Dalihan Na Tolu in Sipirok Sub-district, South Tapanuli Regency, North Sumatera Province. Journal Of Human Behavior In The Social Environment.

Muhammad, A. bin. (2008). Tafsir Ibnu Katsir. Pistola Imán Asy-Syafi'i.

Muhammad Chirzin. (2013). Berinteraksi Dengan Al-quran,. INSYIRAH, Jumal Ilmu Bahasa Arab Dan Studi Islam.

Muhibuddin, et al. (2019). Dayah Strategy of Aceh in Preparing For Professional Advisory in Bireuen District. Budapest International Research and Critics Institute (BIRCIJournal): Humanities and Social Sciences, 514-527.

Mujiyo, M. (2018). Hadis Muttafaq `Alaih Dalam Kitab Riyâdh Al-Shâlihîn. Diroyah : Jurnal Studi Ilmu Hadis. https://doi.org/10.15575/diroyah.v1i2.2065

Nia, M. K. (2016). Tafsīr al-Tabarī and Shi'a Tafsīrs. Journal of Shi'a Islamic Studies. https://doi.org/10.1353/isl.2016.0015

Piloting, T., Pend, J., Fmipa, B., Tumbuhan, P., Hewan, D. A. N., Soediono, B., ... Dali, A. L. \& M. H. (2012). Ulumul Qur 'an. Ulumul Qur'an (Kajian Sejarah Dan Perkembangannya). https://doi.org/10.1017/CBO9781107415324.004

RI, K. A. (2010). al-Quran dan Tafsirnya. Jilid 4.

Rosman, A., \& Samngani, M. (2010). Perbandingan Metodologi Penafsiran Tafsir Al-Azhar Dan Fi Zilal Al-Quran Dalam Surah Al-Ra? Du. ... Penafsiran Tafsir Al-Azhar Dan Fi Zilal ....

Shah, M. (2013). Al-Tabarī and the dynamics of tafsīr: Theological dimensions of a legacy. Journal of Qur'anic Studies. https://doi.org/10.3366/jqs.2013.0097

Shihab, Q. (2009). Tafsir Al-Misbah. HUNAFA: Jurnal Studia Islamika. https://doi.org/10.1177/0146107909106758

Sja’roni. (2014). Studi Tafsir Tematik. Jurnal Studi Islam: Pancawahana. 
Syahnan, M. (2017). I'jâz Al-Qur'ân in the Views of Al-ZamakhsyÂrî and Sayyid Quthb. Ulumuna. https://doi.org/10.20414/ujis.v15i2.198

Syarafuddin. (2017). Tafsir Bi Al-Ma'Sur (Kelebihan Dan Kekurangan Serta Pengembanganya). Suhuf.

Yasir, M. (2013). Kitab Musnad Ahmad Ibn Hanbal. Menara.

Yusuf, M., Zain, A., \& Fuadi, M. (2017). Identifikasi Ayat-Ayat Dakwah Dalam Al-Qur`An. Al-Idarah: Jurnal Manajemen Dan Administrasi Islam. https://doi.org/10.22373/alidarah.v1i2.2674

Zuailan. (2016). Metode Tafsir Tahlili. Diya Al-Afkar: Jurnal Studi Al-Quran Dan Al-Hadis. https://doi.org/10.24235/SQH.V4I01.805

Zulfikar, et al. (2020). TheDa'wahMovement of Ulama Dayah (Analysis the Da'wah Movement of Têungkū Hasanoel Bashry). Britain International of Humanties and Social Sciences (BIoHS) Journal, 90-99.

Zulkifli Hj.Mohd Yusoff. (2003). Tafsir al-Mawdu?i : Kajian Pensejarahan. Al-Bayan Journal of Al-Quran \& Al-Hadith. 